Historic, Archive Document

Do not assume content reflects current scientific knowledge, policies, or practices. 

United States as 762 Department of
Agriculture

Forest

Federts

Service

Forest Pest

Management

Methods

Application

Group

AERIAL PHOTOGRAPHY FOR
ASSESSMENT OF BLACK-TAILED
PRAIRIE DOG MANAGEMENT ON
THE BUFFALO GAP NATIONAL
GRASSLAND, SOUTH DAKOTA

Fort Collins,

Colorado 80524

Uiss

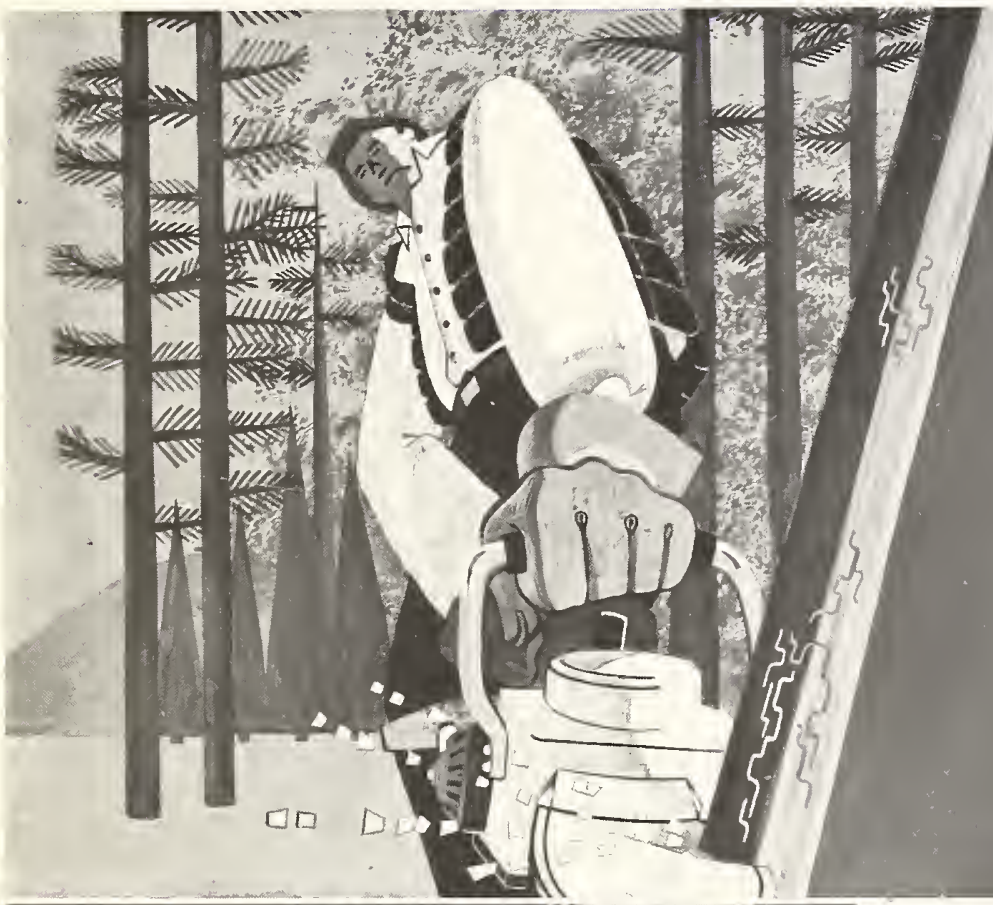

$86 / 7$
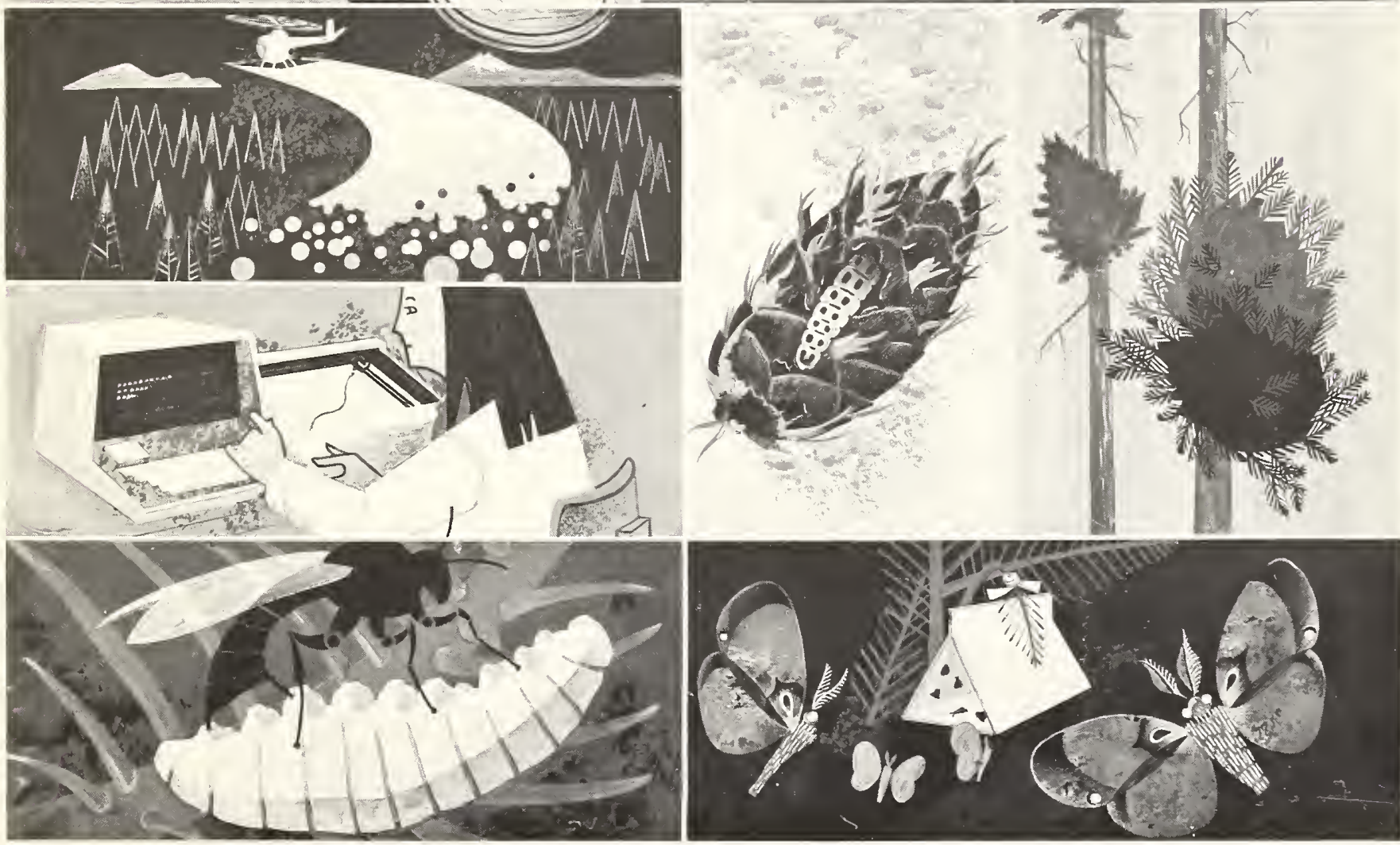
Report No. $86-7$

3400

July 1986

AERIAL PHOTOGRAPHY FOR ASSESSMENT OF BLACK-TAILED PRAIRIE DOG MANAGEMENT ON THE BUFFALO GAP NATIONAL GRASSLAND, SOUTH DAKOTA

by

Greg L. Schenbeck and Richard J. Myhre $1 / 2 /$

\begin{abstract}
Pre- and post-treatment aerial photography was successfully used to assess the effectiveness of a black-tailed prairie dog management program in the Conata Basin of western South Dakota where zinc phosphide bait was used to control a large and rapidly expanding prairie dog population. Five untreated colonies increased 61 percent in area over a 5 -year period while seven treated colonies remained within one percent of their original size during the same time period. A comparison of pre- and post-treatment aerial photography also showed that mound densities within treated colonies decreased over the 5-year period while mound densities in untreated colonies increased. Reductions in mound densities resulted from mound revegetation due to reduced or a lack of prairie dog activity following rodenticide treatments. An inventomy of prairie dog colonies in the Conata Basin was conducted using the posttreatment aerial photography, and a total of 224 colonies covering 23,914 acres was mapped. When compared to the cost of conventional ground methods, the use of aerial photography was cost effective at just over six cents per acre.
\end{abstract}

INTRODUCTION

A program to manage populations of the black-tailed prairie dog, Cynomys ludovicianus, (Figure 1) was initiated on the Buffalo Gap National Grassland in western South Dakota in 1978. This program involved use of a two percent zinc phosphide bait to help control and reduce a large and rapidly expanding

$\underline{1}$ The authors are respectively, Wildlife Management Biologist, USDA Forest Service, Nebraska National Forest, Chadron, NE; and Scientific Photographer, USDA Forest Service, Forest Pest Management/Methods Application Group, Fort Collins, $\mathrm{CO}$.

2/Funding for this work was provided by the National Agricultural Pesticide Impact Assessment Program (NAPIAP); USDA Forest Service, Forest Pest Management; and the Nebraska National Forest. 


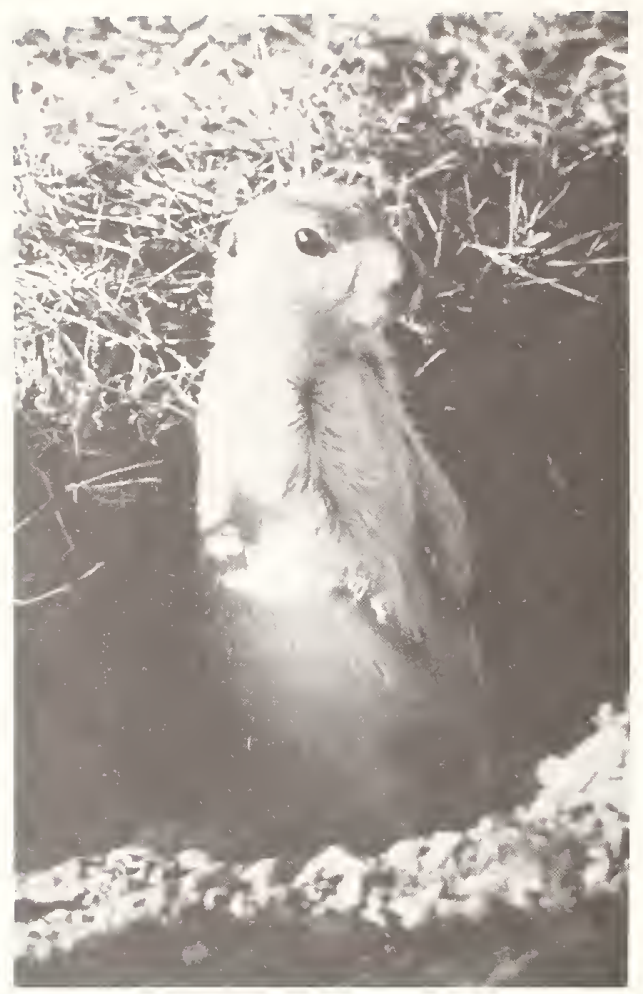

Figure 1. The black-tailed prairie dog, Cynomys 1udovicianus.

prairie dog population. This program was initiated in response to concerns expressed by agricultural interests about the adverse effects of prairie dog feeding and digging (Figure 2) on range condition and livestock forage availability on the National Grassland and intermingled private lands. The program also provided for numerous selected colonies to remain untreated and active to protect the social and environmental values associated with this species.

Initial application of zinc phosphide bait occurred in the fall of 1978 . Application was made in accordance with EPA label instructions, and use of mechanical bait dispensers allowed the application rate to be regulated at four grams per bait spot per burrow opening. Initial treatment of all colonies scheduled for treatment was completed during the fall of 1980 . Follow-up rodenticide treatment of individual colonies was conducted at one to three year intervals after initial application to prevent recovery of the prairie dog population. This report describes the use of aerial photography to assess treatment effects. 


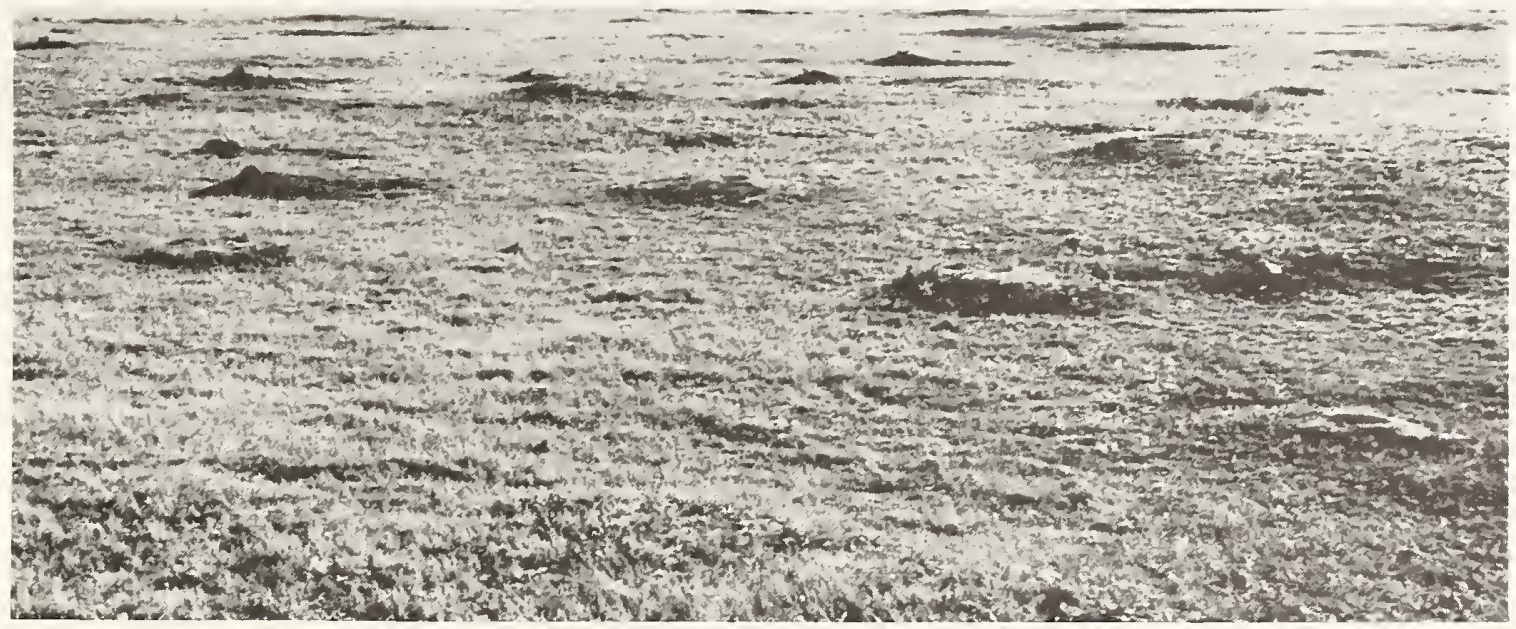

Figure 2. Typical prairie dog colony consisting of numerous burrow mounds, Buffalo Gap National Grassland, South Dakota.

METHODS

DESCRIPTION OF AREA

The evaluation site was in the Conata Basin on the Buffalo Gap National Grassland (Figure 3), an area of approximately 90 square miles. Annual precipitation ranges from 15 to 17 inches. Topography is flat to undulating and frequently dissected by rugged badlands formations. Elevation ranges from approximately 2,300 to 3,000 feet above mean sea level. Vegetation is predominantly short to mid-grasses including western wheatgrass, Agropyron smithii; green needlegrass, Stipa viridula; blue grama, Bouteloua gracilis; and buffalograss, Buchloe dactyloides. Common plants on disturbed sites such as prairie dog colonies, include blue grama; buffalograss; needleleaf sedge, Carex eleocharis; red threeawn, Aristada longiseta; pricklypear, Opuntia compressa; scarlet globemallow, sphaeralcea coccinea; and fetid marigold, Dyssodia papposa. Cattle grazing in the area occurs from mid-May through October and is generally season-long.

AERIAL PHOTOGRAPHY ACQUISITION

Aerial photography acquired prior to treatment (1978) and acquired five years later (1983) was used to evaluate the effectiveness of the treatment program. The 1983 photography was also used to conduct a complete inventory of all prairie dog colonies in Conata Basin.

PRE-TREATMENT PHOTOGRAPHY - Existing aerial photography of prairie dog colonies in Conata Basin was provided by the Denver Wildlife Research Center, U.S. Fish and Wildlife Service. The photography was acquired during the fall 


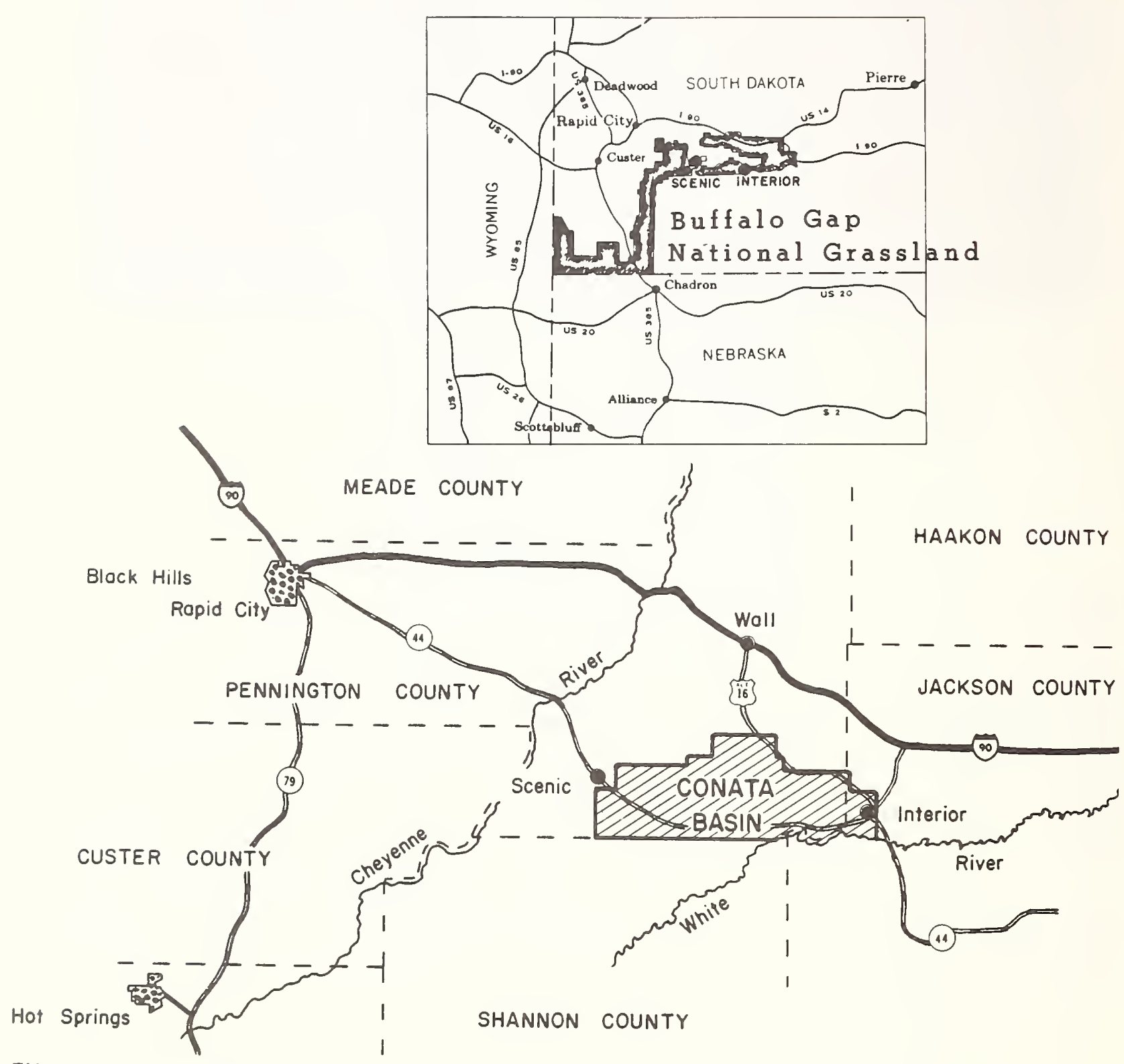

FALL RIVER COUNTY

Figure 3. Location of Conata Basin within the Buffalo Gap National Grassland in western South Dakota. 
of 1978, just prior to the initial rodenticide treatments, at a planned photo scale of approximately 1:16,000, using black and white Kodak Plus X (Type $2402) 3 /$ film and a high contrast filter. Black and white $9 \times 9$ inch paper contact prints were made from the original negative film.

POST-TREATMENT PHOTOGRAPHY - A photo mission was flown over Conata Basin in August 1983 using a Forest Service Beechcraft Queen Air aircraft equipped with a Zeiss RMK 21/23, 9X9 inch format mapping camera and an 8-1/4 inch focal length lens. Photography was acquired at a planned scale of approximately $1: 16,000$ to compare with the 1978 photography. Kodak Aerochrome Infrared (Type 2443) film was used with a Wratten 12 (minus blue) filter and an antivignetting filter, and was processed to a positive transparency. Color infrared film was used because of its ability to penetrate atmospheric haze; its greater sensitivity to vegetation types; and its superior color contrast between living vegetation and bare soil.

NAVIGATION AIDS - Insufficient topographic features on existing 1:62,500 scale U.S. Geological Survey (USGS) maps prompted the use of National High Altitude Photography (NHAP) 1:82,000 scale black and white aerial photos for navigational purposes. The USGS maps were used for photo mission planning and flight line determination (Figure 4). Black and white NHAP photos were assembled into a photo mosaic and annotated with flight lines from the USGS map (Figure 5). The photo mosaic proved to be an excellent navigational aid for locating and flying along flight lines. The mosaic was later used as a photo index map for photo retrieval.

PHOTO INTERPRETATION

PHOTO PREPARATION - Only even numbered frames/photos were used for interpretation and analysis. The 1978 prints were placed in transparent acetate sleeves and secured to the sleeves with clear tape to prevent the film from moving within the sleeve. Processed film rolls from the 1983 photography were cut into individual photos, and each photo was then placed in an acetate sleeve and secured with tape. The camera frame number, fiducial marks, and effective area were delineated on each sleeve for both the 1978 and 1983 photography. Special pens (Pilot, ultra fine point, permanent ink, SC-UF) were used for transcribing all information on the acetate sleeves.

DELINEATION OF COLONIES - Procedures used to delineate prairie dog colonies on the 1978 and 1983 photography were modified from those described by Tietjen, et a1. (1978). Using a 7X pocket magnifier, the effective area of each photo was scanned to locate colonies which appear as concentrations of light colored spots (burrow mounds). The outline of each colony was then delineated on the sleeve while viewing with the magnifier (Figure 6). The 1983 photography was viewed on a quality light table since this film was processed to transparencies.

3/Mention of commercial products is for convenience only and does not imply endorsement by USDA Forest Service. 


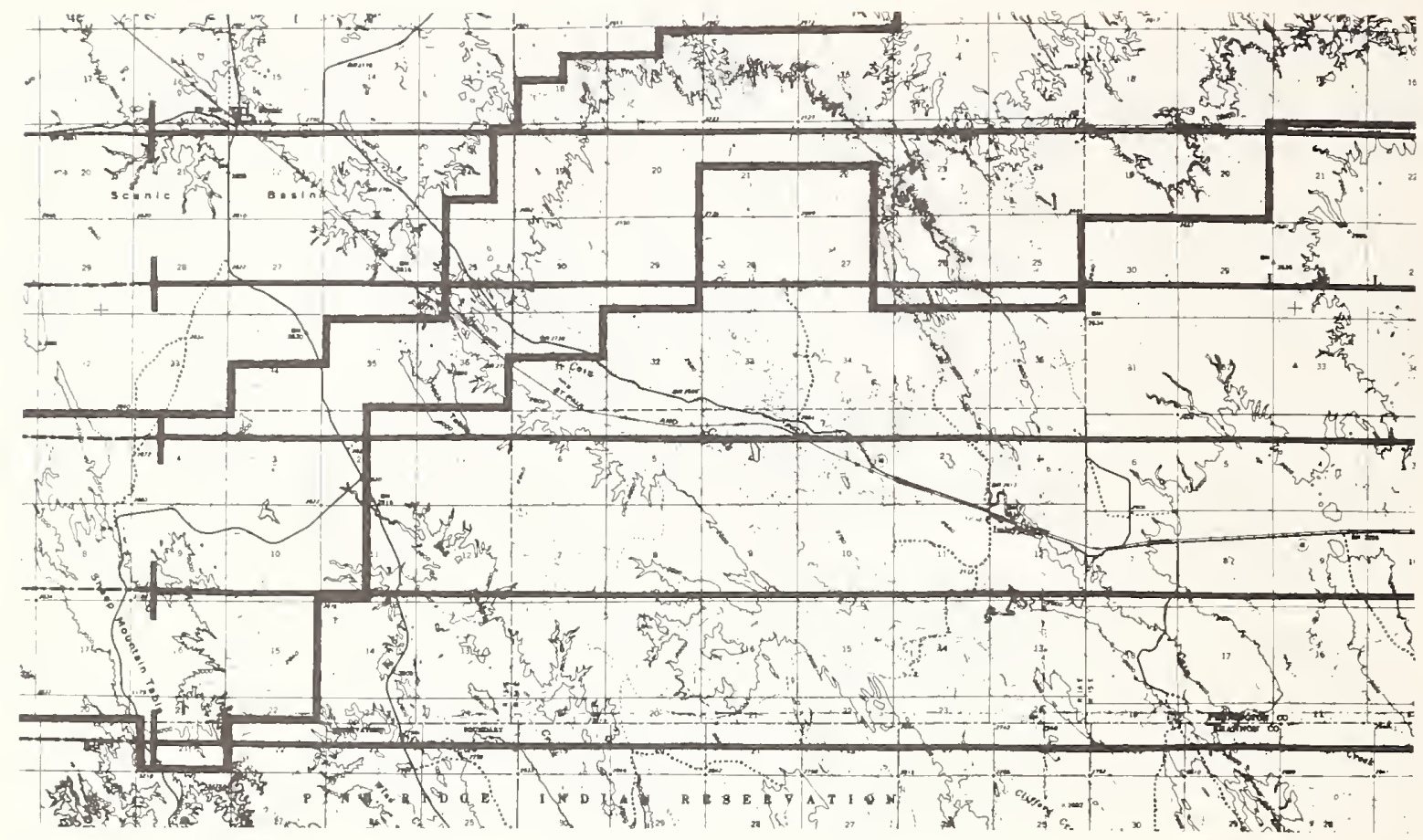

Figure 4. A portion of a USGS map used for planning and establishing aerial photo flight lines, Buffalo Gap National Grassland, South Dakota.

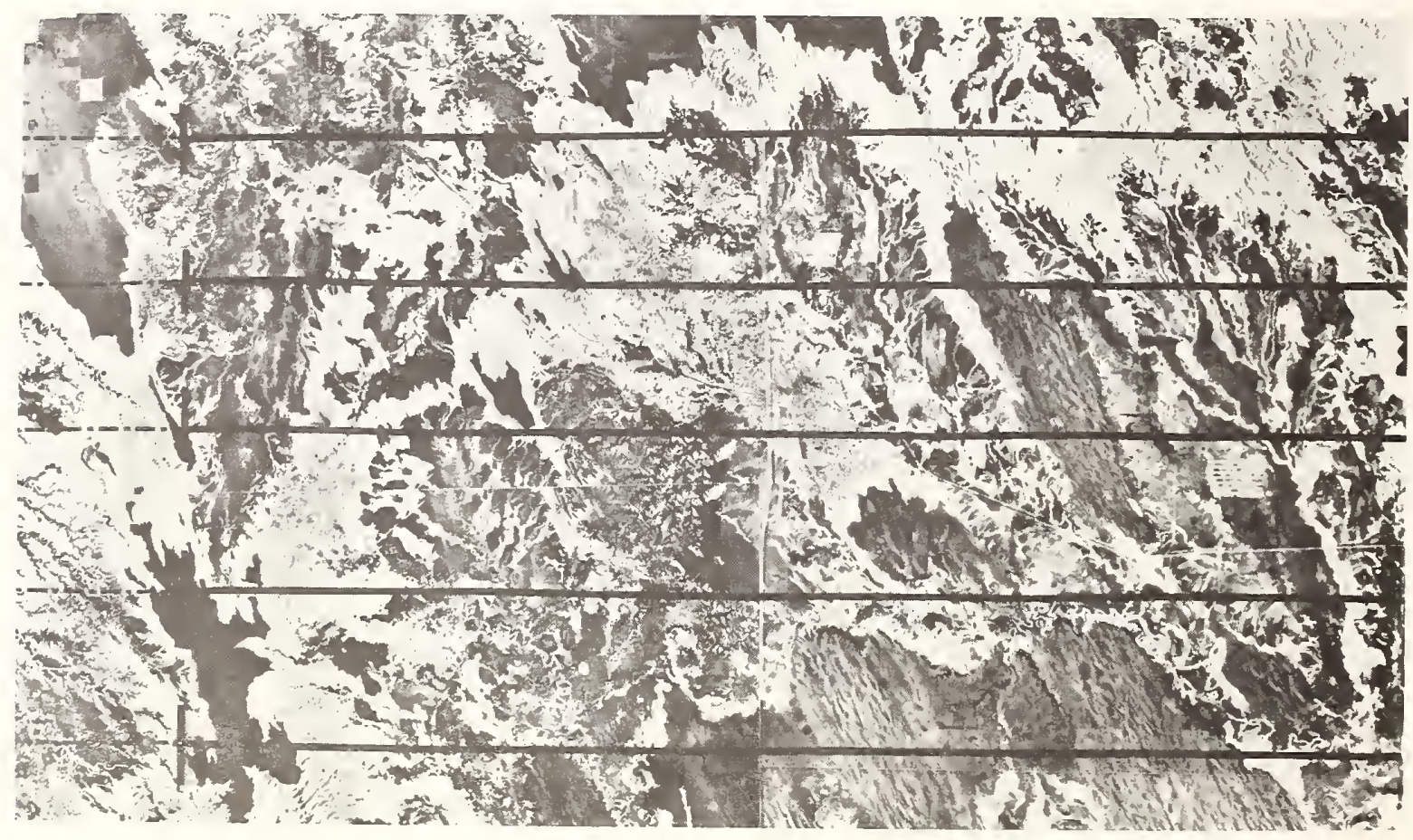

Figure 5. A portion of the National High Altitude Photograph (NHAP) photo mosaic of the Buffalo Gap National Grassland with flight lines. Note the aerially visible terrain features as compared to the map in Figure 4 . 


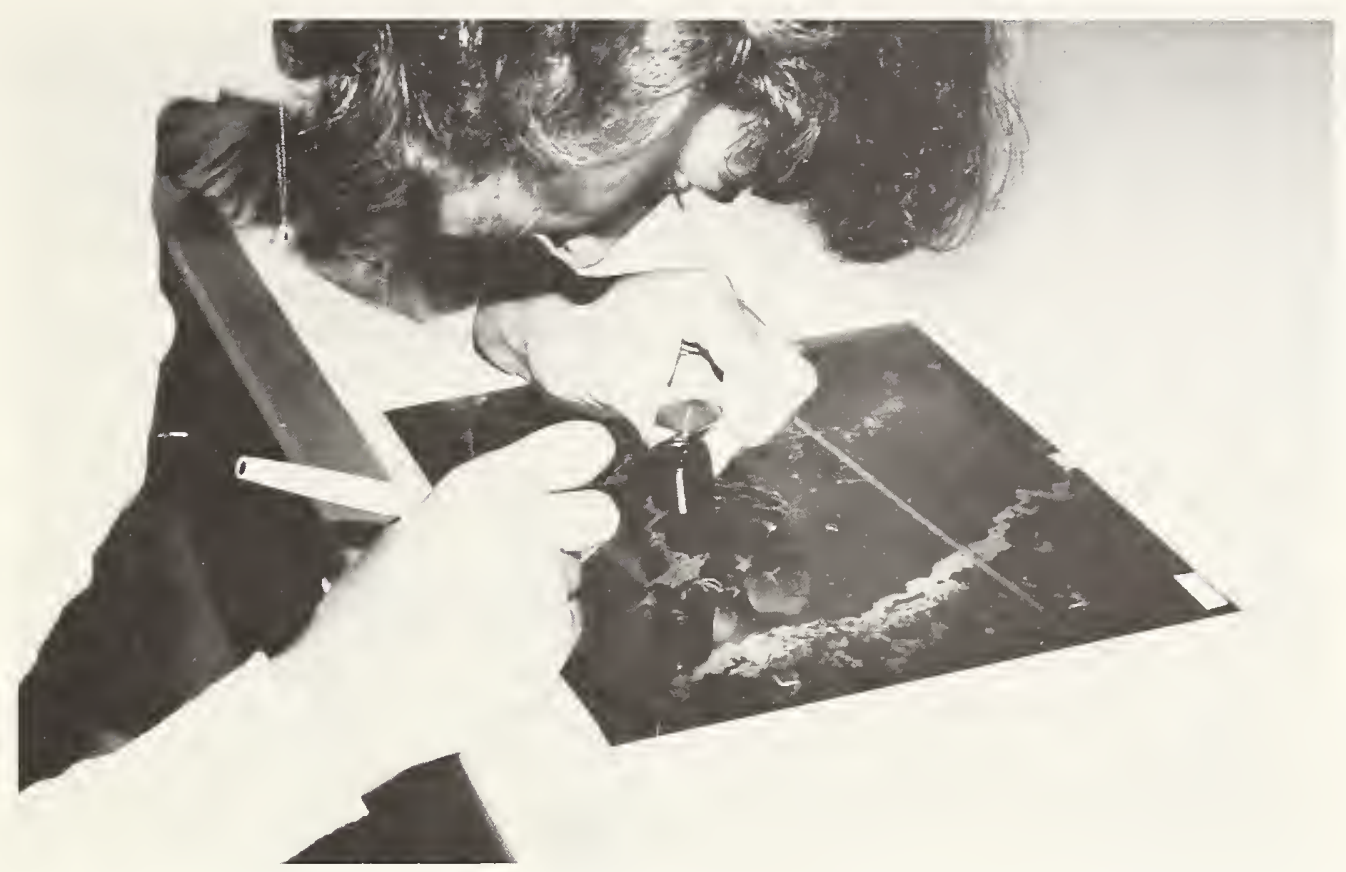

Figure 6. Photo interpreter outlining prairie dog colonies.

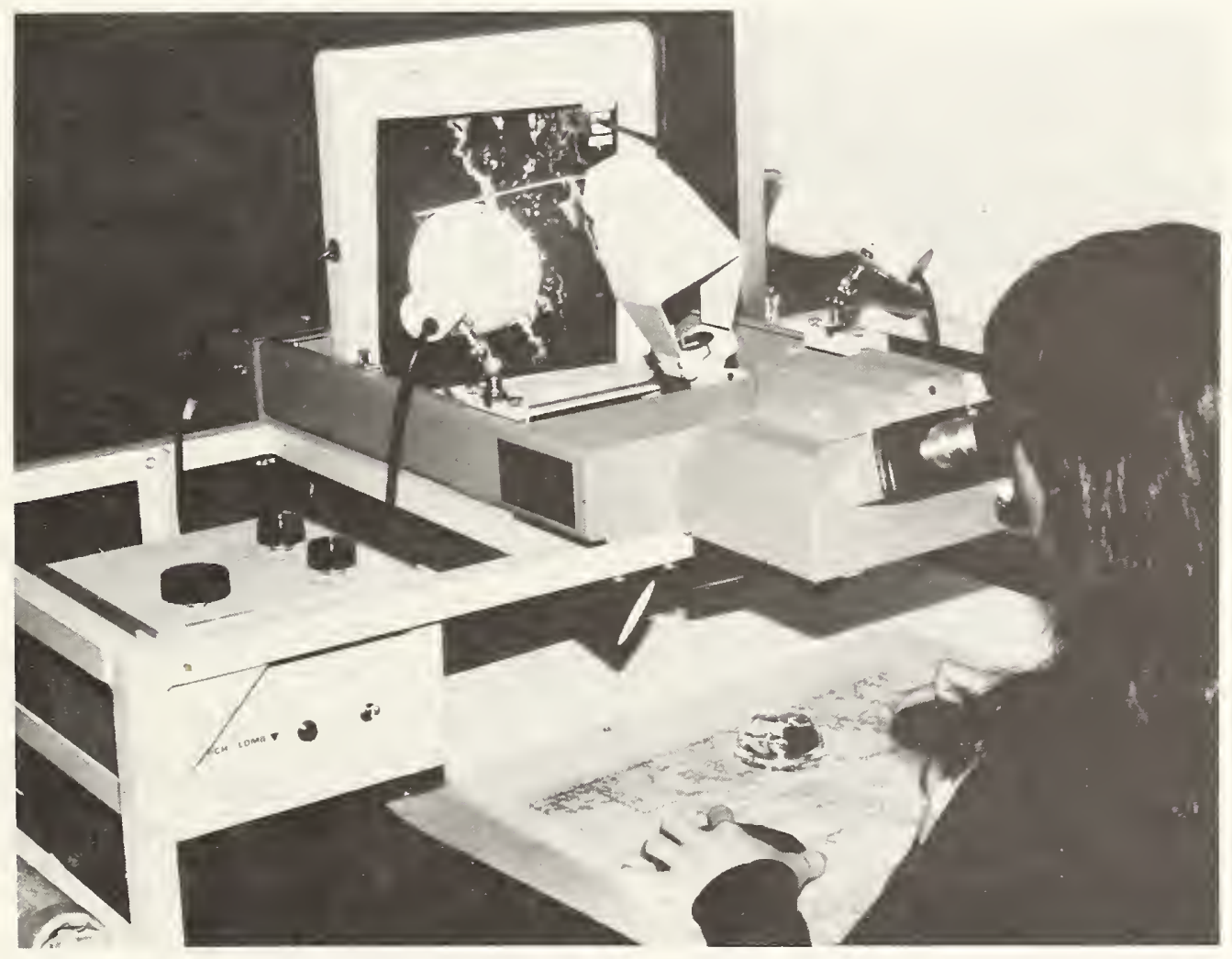

Figure 7. Photo interpreter using a zoom transfer scope to transfer prairie dog colony boundaries to topographical map. 
COLONY AREA DETERMINATION - The outline of each colony was transferred from the aerial photographs to $1: 24,000$ scale USGS topographic maps using a Bausch and Lomb zoom transfer scope (Figure 7). Area (acreage) of each colony was measured on the topographic maps using a Numonics electronic planimeter/ calculator.

GROUND DATA VERIFICATION - Informal ground checks were made to insure that pocket gopher, Geomys spp., diggings were not confused with prairie dog mounds. No other ground surveys were needed.

\section{EVALUATION OF TREATMENT EFFECTIVENESS}

Prairie dog burrow mounds eventually revegetate following effective rodenticide treatments due to a reduction or absence of prairie dog activity. Since mounds which have revegetated do not appear readily on aerial photographs, a comparison of pre- and post-treatment aerial photography of a treated colony can be used to evaluate and quantify treatment effectiveness. When mound revegetation occurs on the edge of a colony, a reduction in colony size can be observed and measured (Figures 8 and 9). When mound revegetation occurs in the interior of a treated colony, a reduction in mound density can be observed (Figures 10 and 11). Treatment effectiveness in the prairie dog management program on the Buffalo Gap National Grassland was evaluated over a 5-year period, 1978 to 1983, for seven colonies that were treated in 1978. Five untreated colonies in the same general area were monitored and used as experimental controls. All treated and untreated colonies had conditions suitable for further colony growth, such as suitable surrounding slopes and no physical barriers like major drainages or badlands ridges. All suitable colonies were used in the evaluation.

INVENTORY OF ALL PRAIRIE DOG COLONIES - The 1983 color infrared photography was also used to conduct a complete inventory of all prairie dog colonies in Conata Basin. All photos were examined for the presence of colonies and the colonies delineated on the film sleeve using the same procedures described in the preceding section.

\section{RESULTS}

\section{EFFECTIVENESS OF TREATMENT}

The five untreated colonies increased 61 percent in area over the 5-year period while the seven treated colonies remained within one percent of their original size during the same time period (Table 1). This indicates that the rodenticide treatments were effective in preventing further expansion of the treated colonies. 


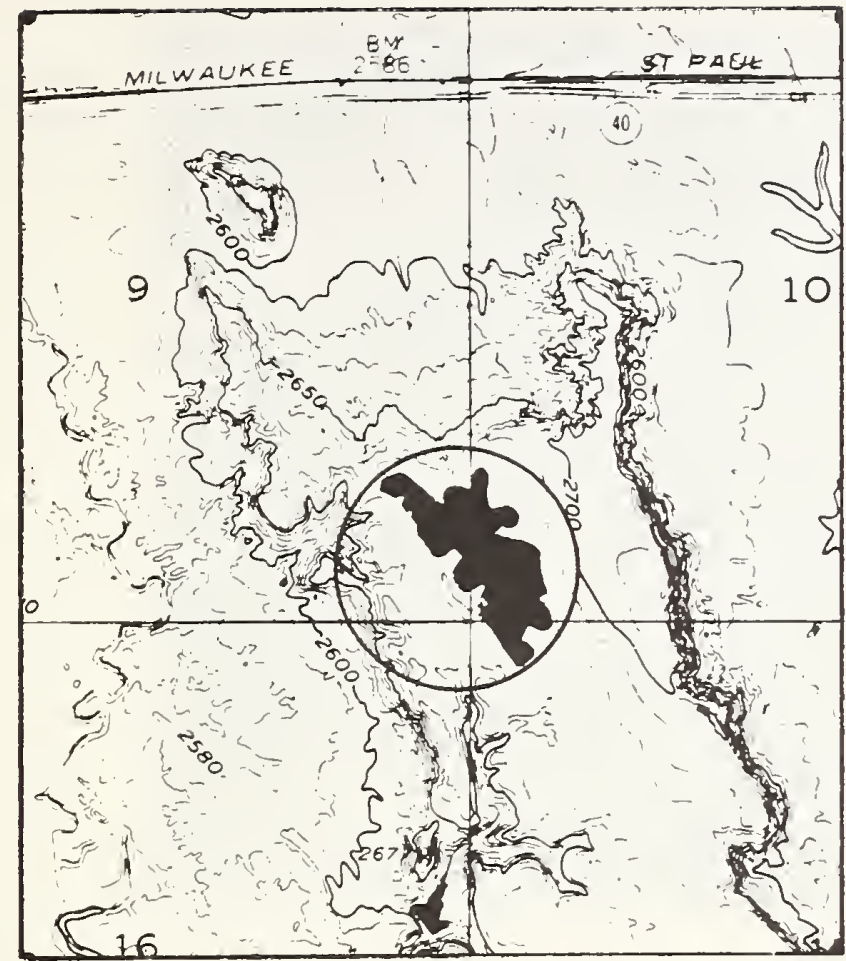

1978

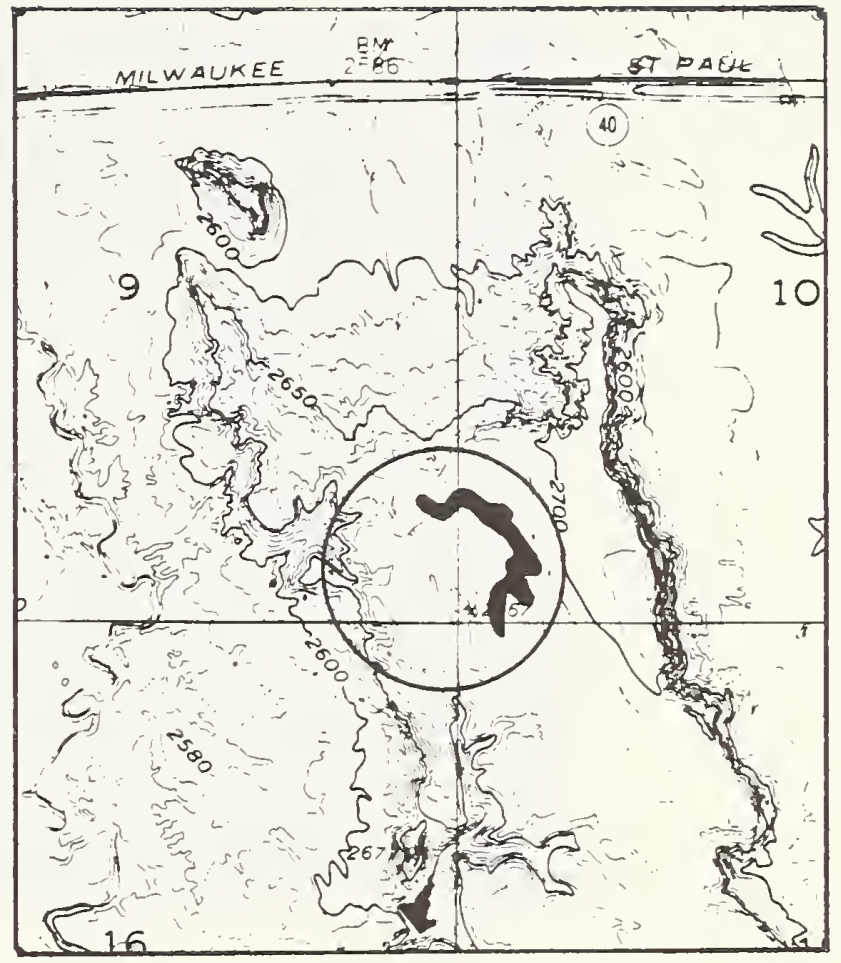

1983

Figure 8. Maps of a treated prairie dog colony showing reduction in colony size from 15.9 acres in 1978 to 4.0 acres in 1983. Circles on maps are for visual comparison of size between years.

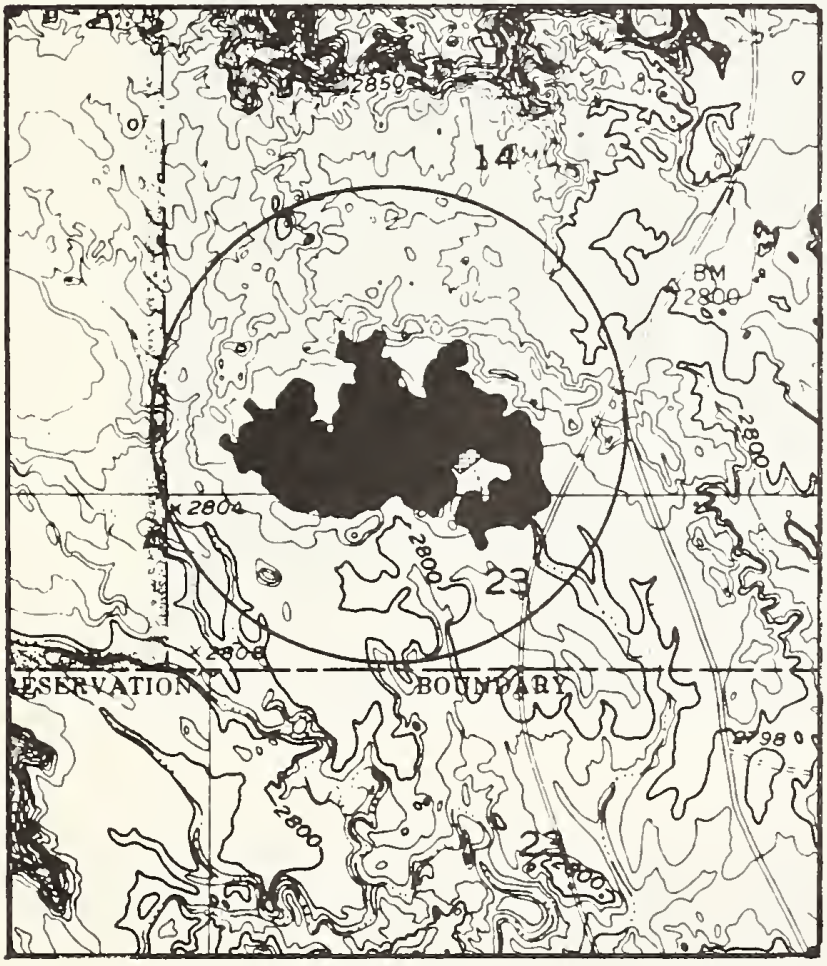

1978

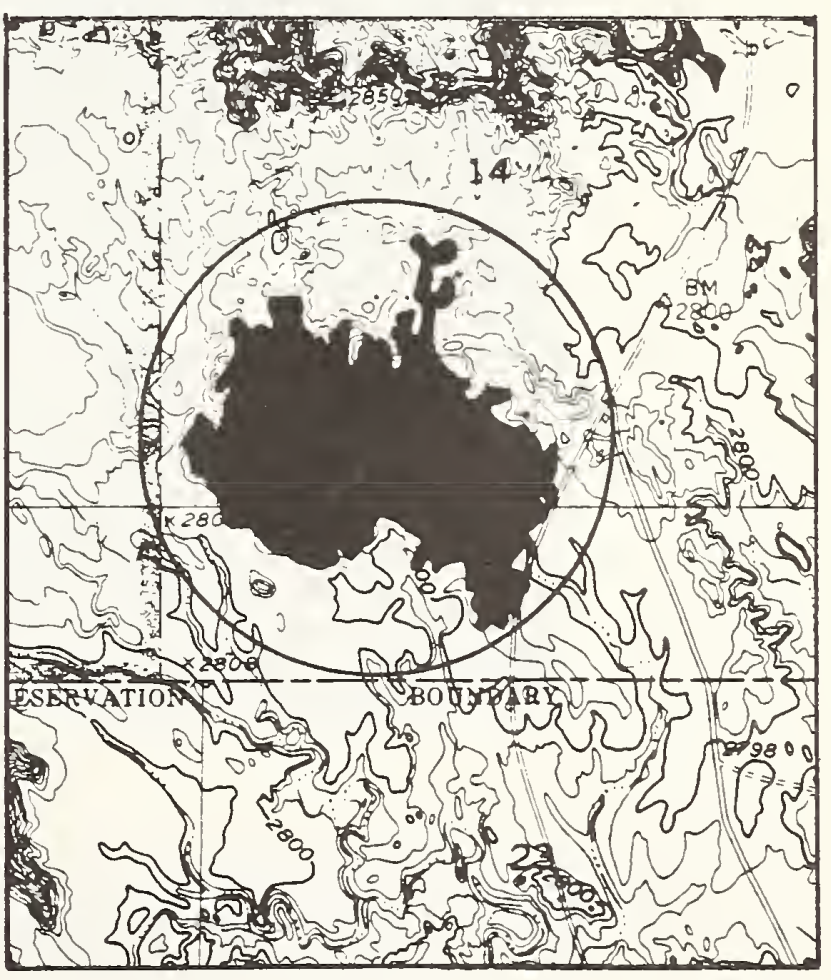

1983

Figure 9. Maps of an untreated prairie dog colony showing an increase in colony size from 48 acres in 1978 to 103 acres in 1983. 


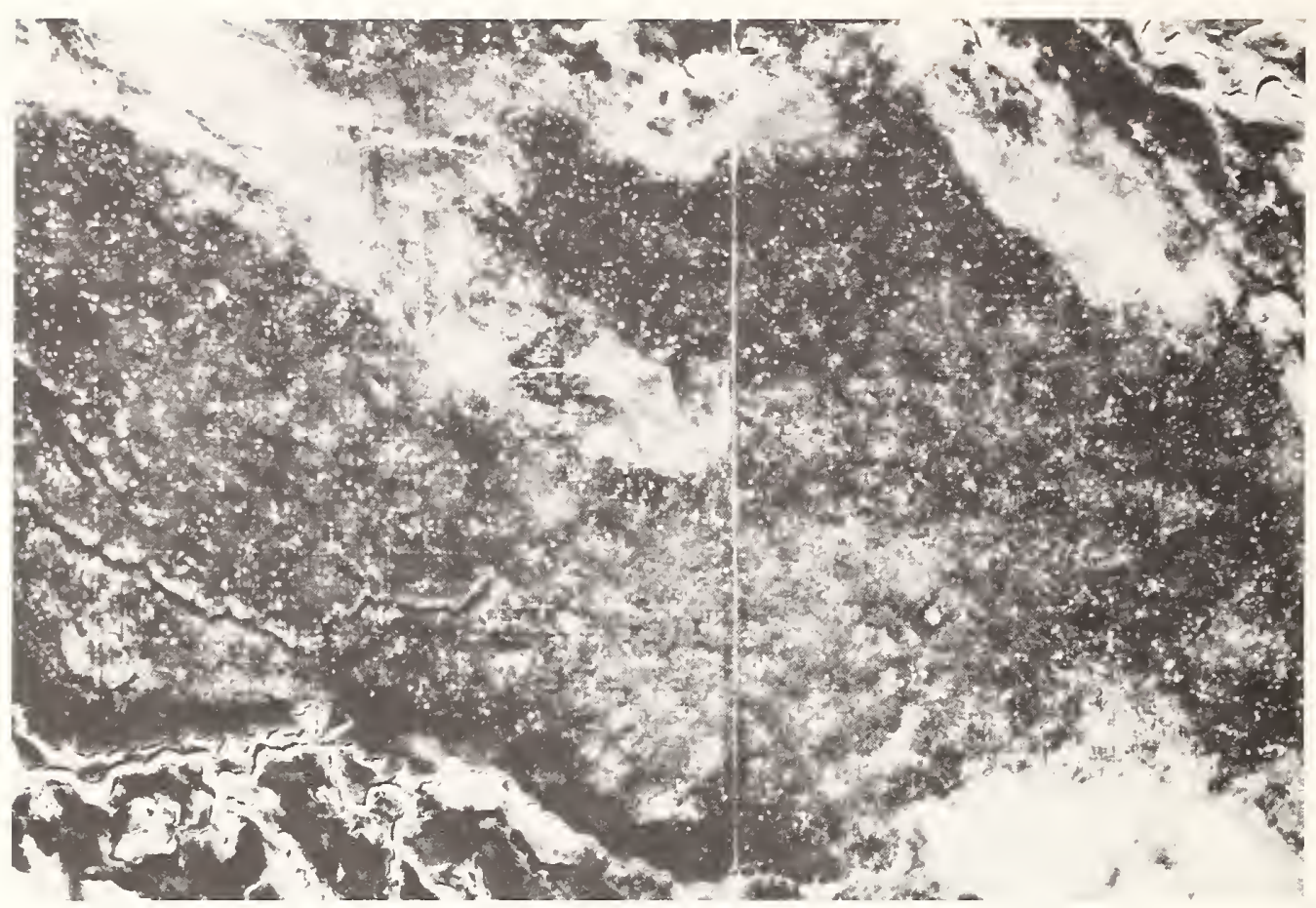

1978

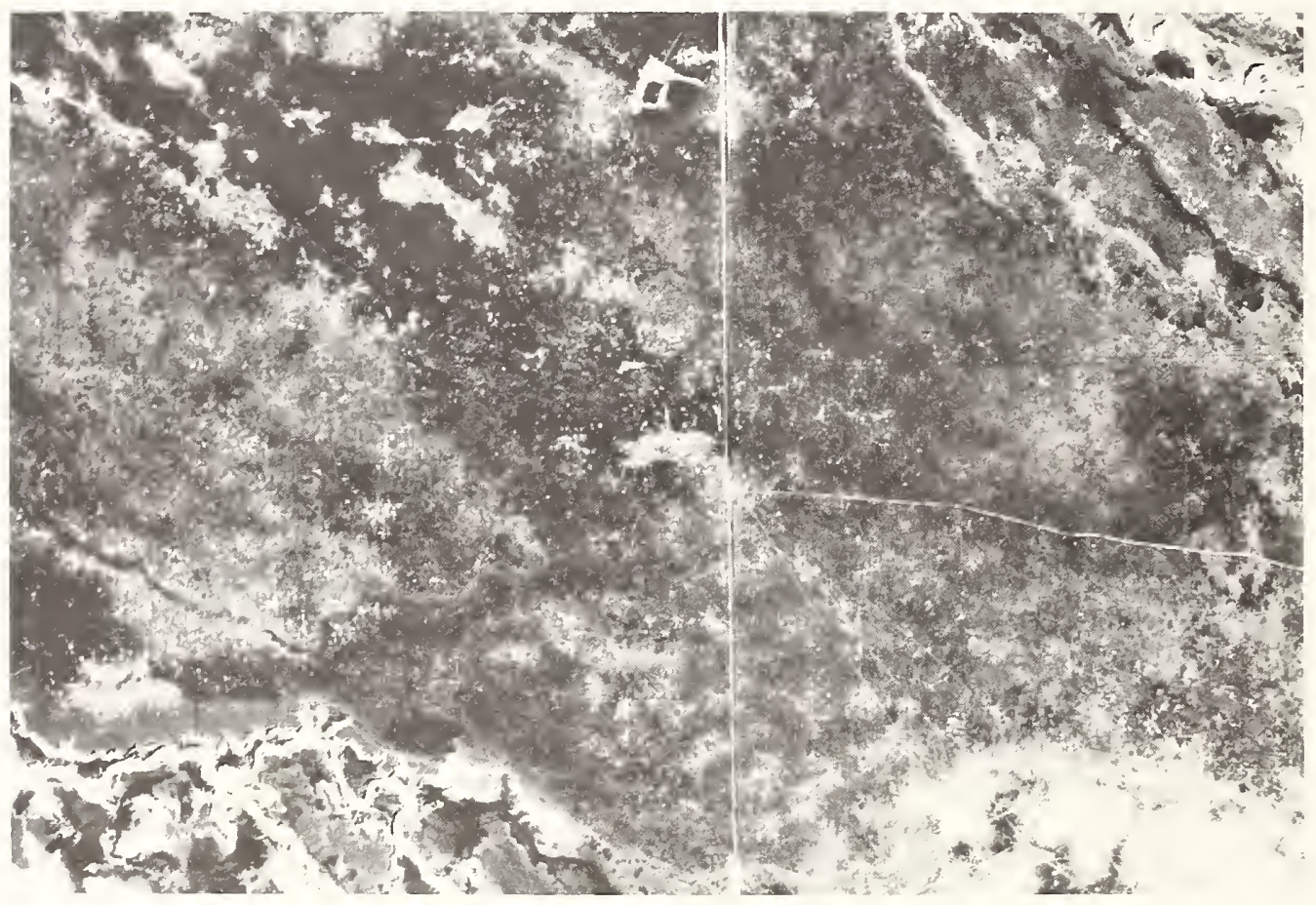

1983

Figure 10. 1978 and 1983 aerial photographs of a prairie dog colony area treated with zinc phosphide, showing a reduction in mound density, Buffalo Gap National Grassland, South Dakota. 


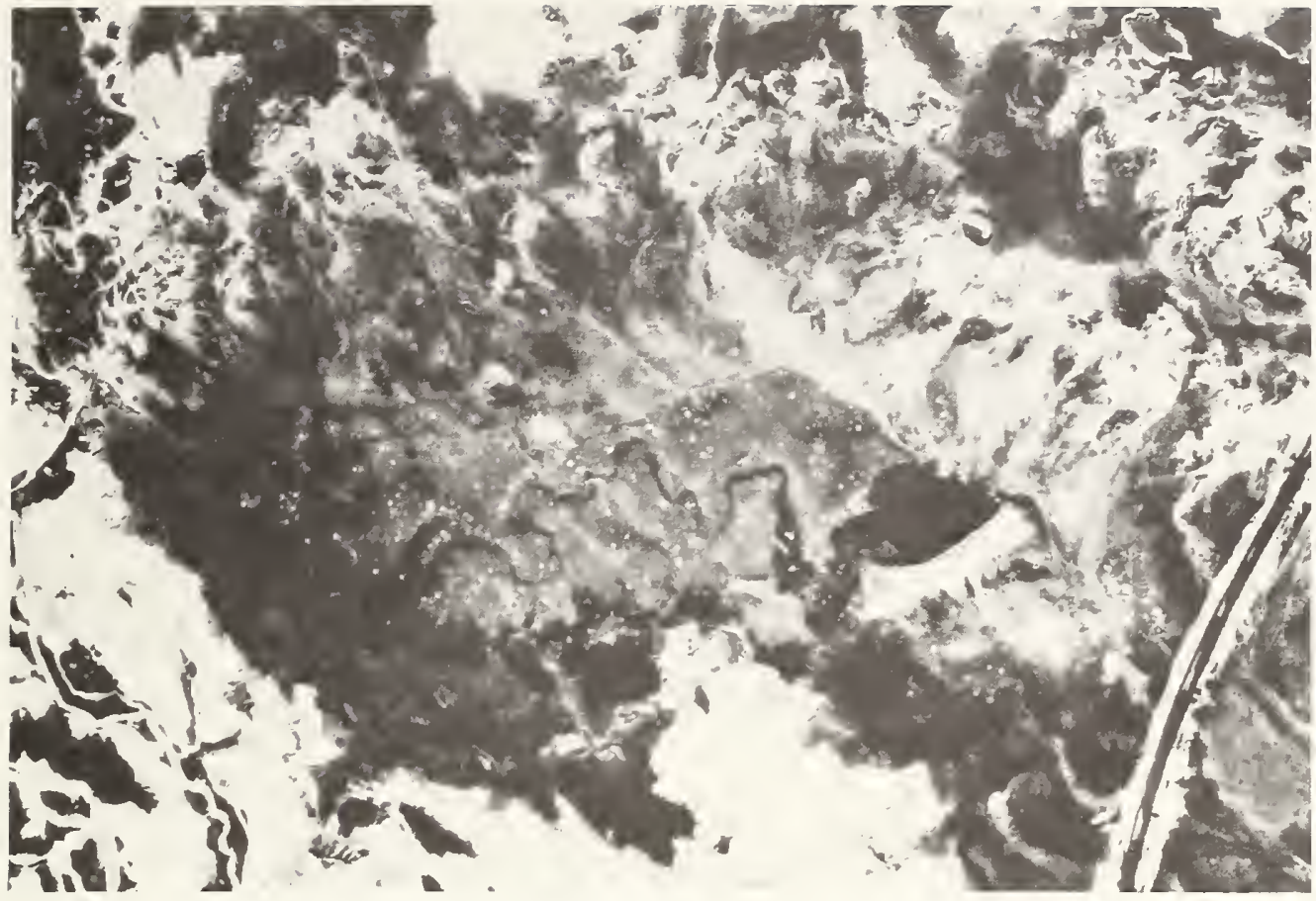

1978

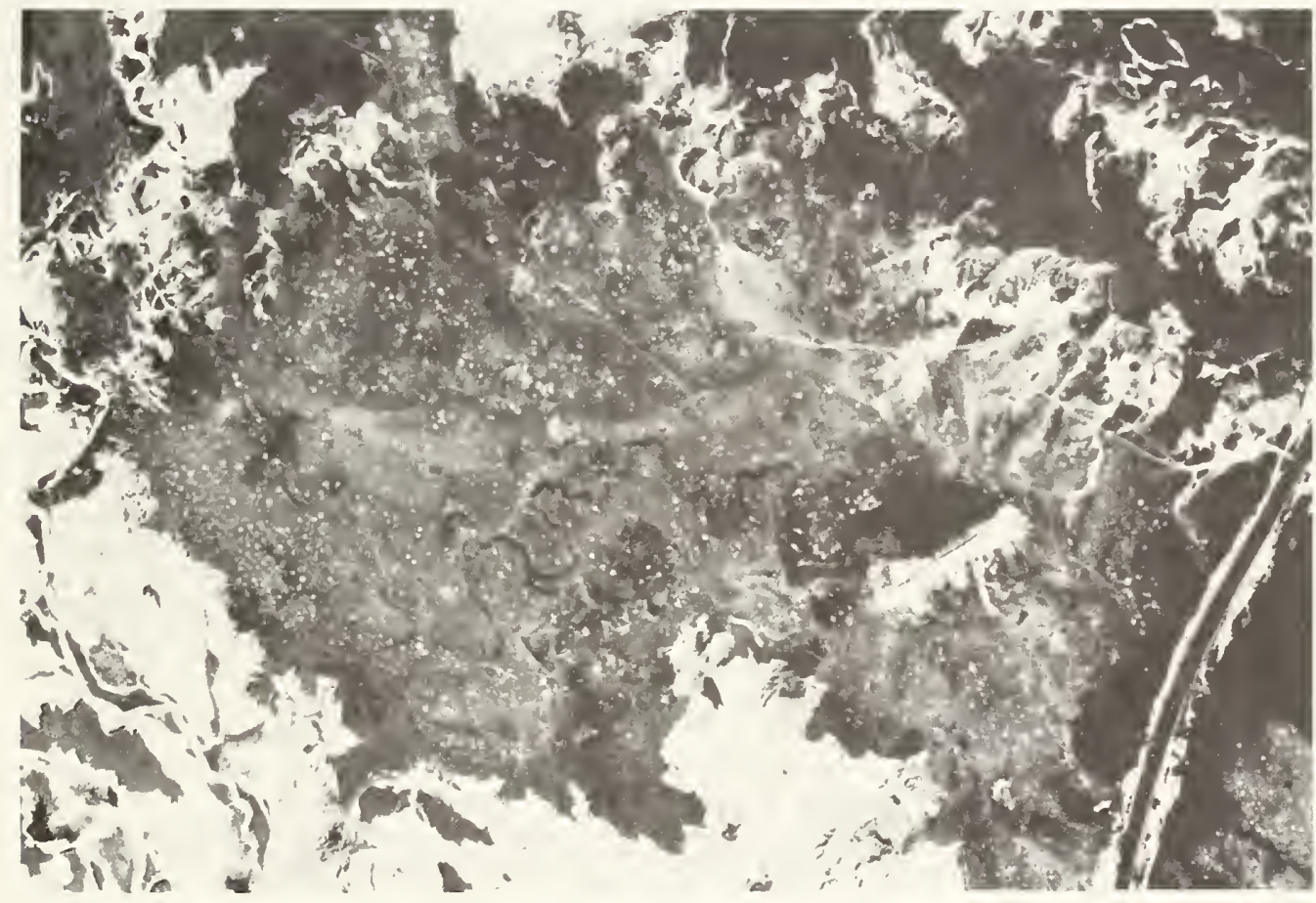

1983

Figure 11. 1978 and 1983 aerial photographs of an untreated prairie dog colony showing a slight increase in mound density and colony area, Buffalo Gap National Grassland, South Dakota. This is the same prairie dog colony that appears in Figure 9. 
Table 1. Comparison of pre- and post-treatment area of black-tailed prairie dog colonies that received zinc phosphide treatments and that remained untreated (experimental controls) on the Buffalo Gap National Grassland, South Dakota.

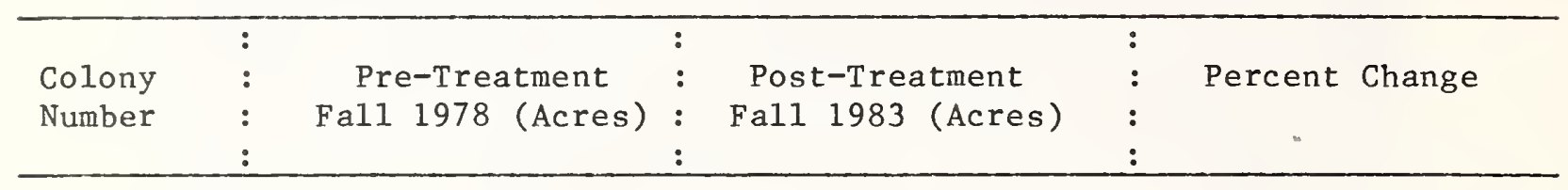

Treated

Colonies

\begin{tabular}{|c|c|c|c|}
\hline 1 & 964 & 940 & -2 \\
\hline 2 & 599 & 656 & +10 \\
\hline 3 & 469 & 418 & -11 \\
\hline 4 & 319 & 364 & +14 \\
\hline 5 & 44 & 40 & -9 \\
\hline 6 & 47 & 39 & -17 \\
\hline 7 & 8 & 10 & +25 \\
\hline$(1-7)$ & 2,450 & 2,467 & +1 \\
\hline \multicolumn{4}{|c|}{$\begin{array}{r}\text { Untreated } \\
\text { Colonies }\end{array}$} \\
\hline 8 & 65 & 111 & +71 \\
\hline 9 & 48 & 103 & +115 \\
\hline 10 & 49 & 62 & +27 \\
\hline 11 & 44 & 96 & +118 \\
\hline 12 & 84 & 94 & +12 \\
\hline$(8-12)$ & 290 & 466 & +61 \\
\hline
\end{tabular}


Photographic comparisons of the treated and untreated colonies showed that mound densities in treated colonies decreased over the 5-year period while mound densities in untreated colonies increased (Figures 10 and 11). It was concluded from these observations that rodenticide treatments had not only prevented further colony expansion, but had also reduced prairie dog activity in treated colonies to a low enough level for mound revegetation to occur.

\section{PRAIRIE DOG COLONY INVENTORY}

The 1983 color-IR photography was used to conduct a complete inventory of all prairie dog colonies (treated and untreated) in the Conata Basin. A total of 224 individual colonies covering 23,914 acres were inventoried on the Buffalo Gap National Grassland. The smallest colony detected was 0.2 acres in size and the largest colony covered 4,046 acres. Many of these colonies had been treated with zinc phosphide and were in the process of revegetating; however, they still appeared as colonies on the aerial photography.

\section{COST EFFECTIVENESS}

The application of aerial photography not only proved to be an operationally effective technique, but a cost effective technique. Detailed cost figures were kept for all phases of the aerial photography operations. In reality, a much larger area of the Buffalo Gap National Grassland was flown than just Conata Basin. The intensive photo interpretation and analysis phase was conducted only on the Conata Basin area; therefore, separate cost per acre figures were determined for the two operational phases.

Aerial photo acquisition was conducted over an area of 230 square miles $(147,200$ acres) at a cost of $\$ 0.025$ per acre. Included in this cost were: (1) round trip aircraft ferry; (2) flight time on photo mission; (3) pilot's salary; (4) standby charges for aircraft; (5) per diem for flight crew of two; and (6) film purchasing and processing.

Intensive photo interpretation was conducted on only 92 square miles $(58,880$ acres) of the original 230 square miles photographed. The total cost of photo interpretation, transfer of colonies from photos to a map base, and measurement of colony acreages was $\$ 0.04$ per acre. Included in this cost were: (1) photo interpretation materials; (2) salary; and (3) per diem for photo interpreter.

Since no large scale ground inventories for locating and mapping all colonies in Conata Basin have been conducted, field/ground operation costs were not available. Time and labor intensive prairie dog ground surveys were conducted in 1977 in the Wind Cave National Park in southwestern South Dakota (Dalsted et al. 1981). These surveys were done on foot using a compass and measuring wheel or a rod and transit. Their cost per acre varied inversely with the size of the prairie dog town, ranging from $\$ 2.51 /$ acre on a 556 acre town to $\$ 9.23 /$ acre on a 39 acre town. These cost figures are based on 1977 ground survey costs. 
DISCUSSION

There are two practical methods for evaluating the effectiveness of rodenticide treatments in operational prairie dog control programs:

1. Measuring the percent reduction in prairie dog activity following treatment.

2. Monitoring vegetation recovery (mound revegetation) following application.

The first method requires a considerable amount of field work and involves plugging burrow openings and counting the number reopened after treatment. The second method is an indirect assessment of measuring treatment effectiveness since it deals with colony growth or reduction and vegetation recovery rather than a direct assessment of prairie dog mortality. This method is also limited to providing a long-term assessment of treatment effectiveness since several years are required following treatment for changes in colony size and mound density to become apparent on aerial photographs.

Medium scale aerial photographs are useful in evaluating the effectiveness of rodenticide treatments by monitoring colony size and mound density. Based on this evaluation, it appears that a minimum of five years is needed between baseline (pre-treatment) and followup (post-treatment) photography to detect measurable changes in colony size and mound density due to revegetation. Less time might be adequate in areas with increased precipitation because of a quicker vegetation response.

The use of aerial photography to estimate treatment effectiveness through vegetation recovery has some advantages over direct assessments of prairie dog mortality. One advantage of using aerial photography is that it provides a quantitative and visual assessment of treatment effectiveness that is indisputable, especially if aerial photography of untreated colonies in the same general area is available for comparisons. This method is also very cost effective.

Aerial photography obtained for assessment of prairie dog management is useful for other purposes. The Buffalo Gap National Grassland photography has also been used for range management planning, updating existing maps, and also serves as a permanent record of vegetation in and around prairie dog colonies. 
The following individuals contributed significantly to the success of this project: Robert Hedrix, Pilot, USDA Forest Service, Rocky Mountain Region, Denver, Colorado, for flying the photo mission; Kathleen Fagerstone, Research Biologist, USDI Fish and Wildlife Service, Denver Wildlife Research Center, Denver, Colorado, for general technical assistance; Patricia 0'Connell, Biological Technician, Nebraska National Forest, Chadron, Nebraska, for photo interpretation and map transfer; and Daniel Uresk, Research Biologist, USDA Forest Service, Rocky Mountain Forest and Range Experiment Station, Rapid City, South Dakota, for technical assistance.

\section{LITERATURE CITED}

Dalsted, K.J., S. Sather-Blair, B.K. Worcester, and R. Klukas. 1981. Application of remote sensing to prairie dog management. J. Range Manage. 34: 218-223.

Tietjen, H.P., J.F. Glahn, and K.A. Fagerstone. 1978. Aerial photogrammetry: a method for defining black-tailed prairie dog colony dynamics. Paper presented at the Pecora IV Symposium on Application of Remote Sensing Data to Wildife Management, Sioux Falls, SD, $4 \mathrm{pp}$. 




$$
\text { ' }
$$

